\title{
Shadow Economies Around the World What Did We Learn Over the Last 20 Years?
}

\author{
LEANDRO MEDINA \\ (INTERNATIONAL MONETARY FUND)
}

The Economics of Informality

May 28-29, 2018

Bogota, Colombia 


\section{Motivation}

"The informal (shadow, black, unreported) economy comprises economic activities that circumvent costs and are excluded from the benefits and rights incorporated in laws and administrative rules covering property relationships, commercial licensing, labor contracts, torts, financial credit, and social systems"

- Feige (2005) 


\section{Why do we care?}

We should be interested in measuring the scale and causes of informal economic activity because:

- It is large and persistent, severely limits tax revenues for developing countries

- Low productivity.

- Provides employment and income (safety net). 


\section{Literature Review}

Direct approach

- Surveys and samples based on voluntary replies, tax audits, other compliance methods

- Results sensitive to the way the questionnaire is formulated or willingness to cooperate

- Therefore, not very successful

\section{Indirect approach / indicator based}




\section{Literature Review}

\section{Discrepancy between expenditure and income statistics}

$$
\text { MacAfee (1980), Yoo and Hyun (1998) }
$$

- Theory

Difference between national expenditures and income approximates informal economy size.

- Drawback

Assumes all expenditure and income measures constructed without error. 


\section{Literature Review}

\section{Discrepancy between official and actual labor force}

Contini (1981), DelBoca (1981), O'Neil (1983)

- Theory

If total labor force constant, declines in official labor force imply informal activity.

- Drawback

Fluctuations in labor force participation. 


\title{
Literature Review
}

\section{Electricity approach}

\author{
Kaufmann and Kalibarda (1996)
}

- Theory

Electricity consumption best indicator of GDP, estimated elasticity of close to one.

- Drawback

- Not all informal activities require electricity.

- Elasticity may vary across countries and time. 


\section{Literature Review}

\section{Transaction approach}

Feige (1979), Boeschoten and Fase (1984), Langfeldt (1984)

- Theory

Fischer's quantity equation $\boldsymbol{M} \times \boldsymbol{V}=\boldsymbol{P} \times \boldsymbol{Q}$ use money supply and estimates of velocity to derive informal activity.

- Drawback

Estimates of velocity may not be constant due to development of check and credit cards. 


\section{Literature Review}

\section{Currency demand approach}

Tanzi (1980)

- Theory

Increased informal activity rises demand for currency, after controlling for other factors can isolate excess demand.

- Drawback

- Potentially underestimate as all transactions might not be in cash.

- Arbitrary to assume equal velocity in both sectors. 


\section{Literature Review}

\section{Multiple Indicators Multiple Causes (MIMIC)}

Schneider and Enste (2000)

Causes/ Drivers
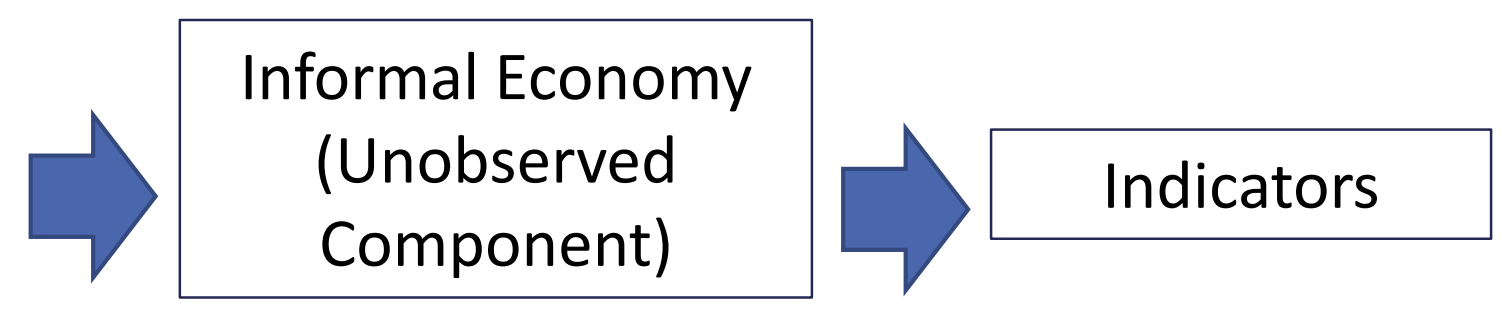

- The MIMIC method treats the informal economy as a latent, unobserved variable which we cannot measure directly.

- We have measures for its potential causes and indicators.

- By setting up a system of equations, under a set of assumptions, we can infer a standardized measure for the informal economy. 


\section{Size of the informal economy}

Causes / Drivers

Informal Economy

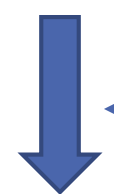

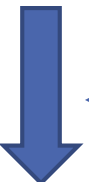

158 countries 1991-2015

Informal Economy

(Standardized)

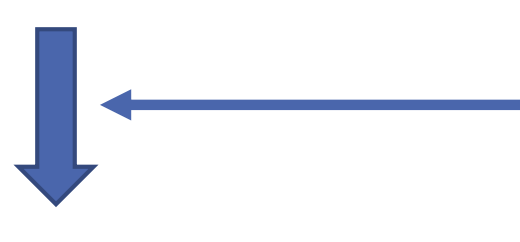

Calibration:

Independent method (one year)

Informal Economy

(Percent of GDP) 


\section{Size of the informal economy}

- Drivers of the informal economy:

- Fiscal freedom. Measure of tax burden on the economy

- Institutions. Lack of respect for the law or high corruption would encourage informal economic activity.

- Unemployment.

- Trade openness. As international trade increases, harder to hide trade from authorities

- Indicators of the informal economy:

- Currency as a fraction of brad money (People engaged in the informal economy usually conduct their activities in cash).

- Labor force participation.

- A measure of the size of the economy using night lights. 


\section{Baseline results}

\begin{tabular}{|c|c|c|c|c|c|c|}
\hline & (1) & $(2)$ & (3) & $(4)$ & (5) & (6) \\
\hline \multicolumn{7}{|l|}{ Causes } \\
\hline Trade openess & $-0.086^{\star \star \star}$ & $-0.085^{\star \star \star}$ & $-0.137^{\star \star \star}$ & $-0.086^{\star \star \star}$ & $-0.086^{\star * \star}$ & $-0.113^{\star * *}$ \\
\hline GDP per capita & $-0.332^{\star \star \star}$ & $-0.335^{\star \star \star}$ & $-0.370^{\star \star \star}$ & $-0.298^{\star * \star}$ & $-0.302^{\star \star \star}$ & $-0.334^{\star \star \star}$ \\
\hline Unemployment rate & $0.051^{* *}$ & $0.054^{\star \star *}$ & $0.069^{* * *}$ & $0.053^{\star *}$ & $0.057^{\star \star \star}$ & $0.069^{* * *}$ \\
\hline Size of government & $0.102^{* * *}$ & $0.102^{* \star *}$ & $0.111^{* * *}$ & & & \\
\hline Fiscal freedom & & & & $-0.131^{\star \star \star}$ & $-0.134^{* * *}$ & $-0.147^{* * *}$ \\
\hline Rule of law & $-0.049^{\star \star *}$ & & & $-0.060^{* * *}$ & & \\
\hline Control of corruption & & $-0.042^{* \star *}$ & & & $-0.046^{\star *}$ & \\
\hline Government stability & & & $-0.054^{* * *}$ & & & -0.015 \\
\hline \multicolumn{7}{|l|}{ Indicators } \\
\hline Currency & 1 & 1 & 1 & 1 & 1 & 1 \\
\hline Labor force participation rate & $-0.521^{* \star *}$ & $-0.532^{\star \star \star}$ & $-0.310^{\star \star *}$ & $-0.452^{\star \star \star}$ & $-0.468^{* \star *}$ & $-0.249^{* * *}$ \\
\hline Growth of GDP per capita & $-0.208^{* *}$ & $-0.245^{\star * \star}$ & $-0.386^{\star * *}$ & -0.113 & $-0.144^{*}$ & $-0.157^{* * *}$ \\
\hline \multicolumn{7}{|l|}{ Statistical Test } \\
\hline RMSEA & 0.073 & 0.073 & 0.067 & 0.078 & 0.078 & 0.055 \\
\hline$x^{2}$ & 513.407 & 506.43 & 649.062 & 508.189 & 500.667 & 535.332 \\
\hline Observations & 1897 & 1892 & 2350 & 1758 & 1757 & 1998 \\
\hline Countries & 151 & 151 & 122 & 144 & 144 & 120 \\
\hline
\end{tabular}




\section{Size of the informal economy}

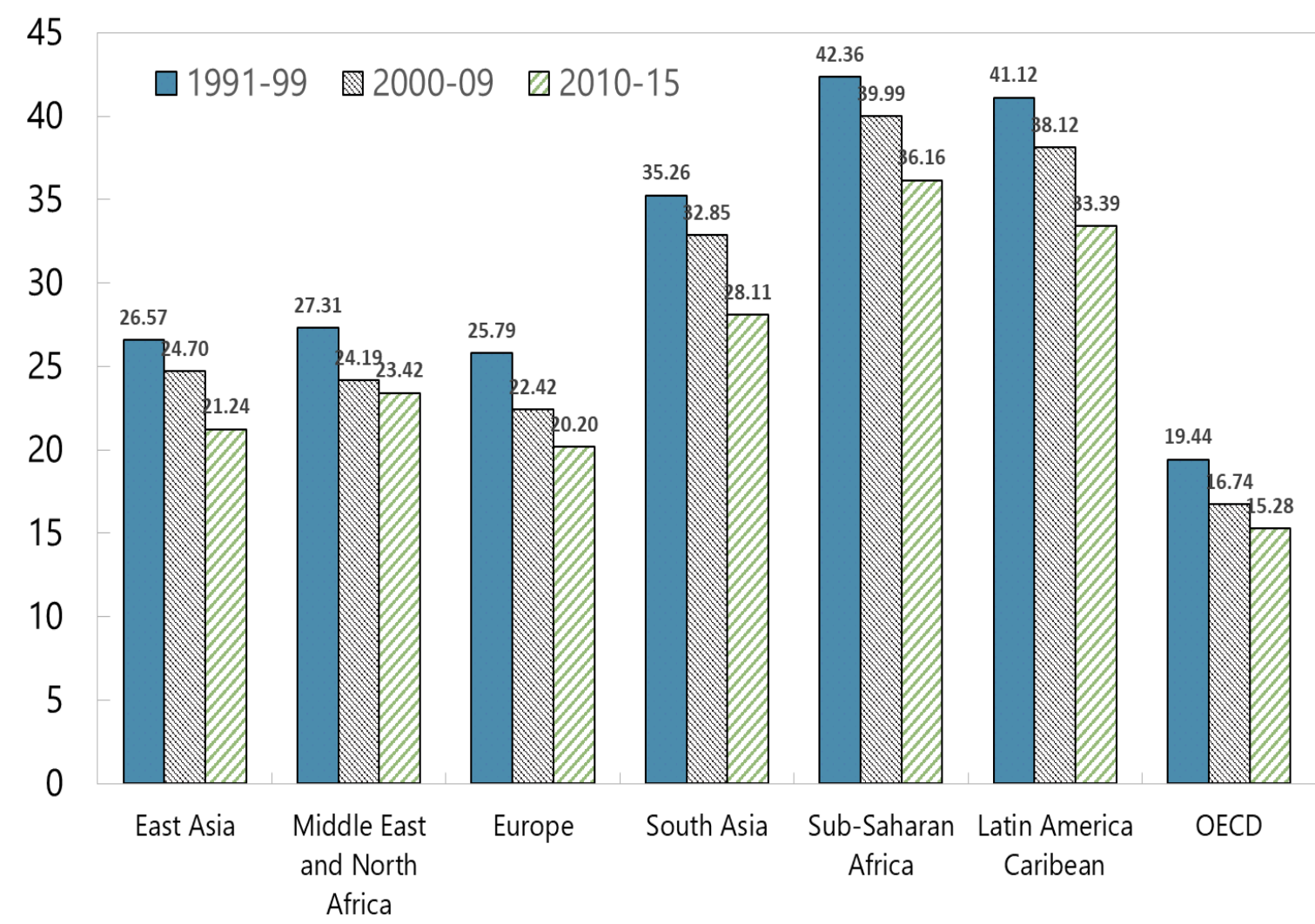

- Size of the informal economy (\% of GDP) large in SSA and Latin America.

- Informality has decreased overtime.

- Wide variety within regions. 


\section{Size of the informal economy}

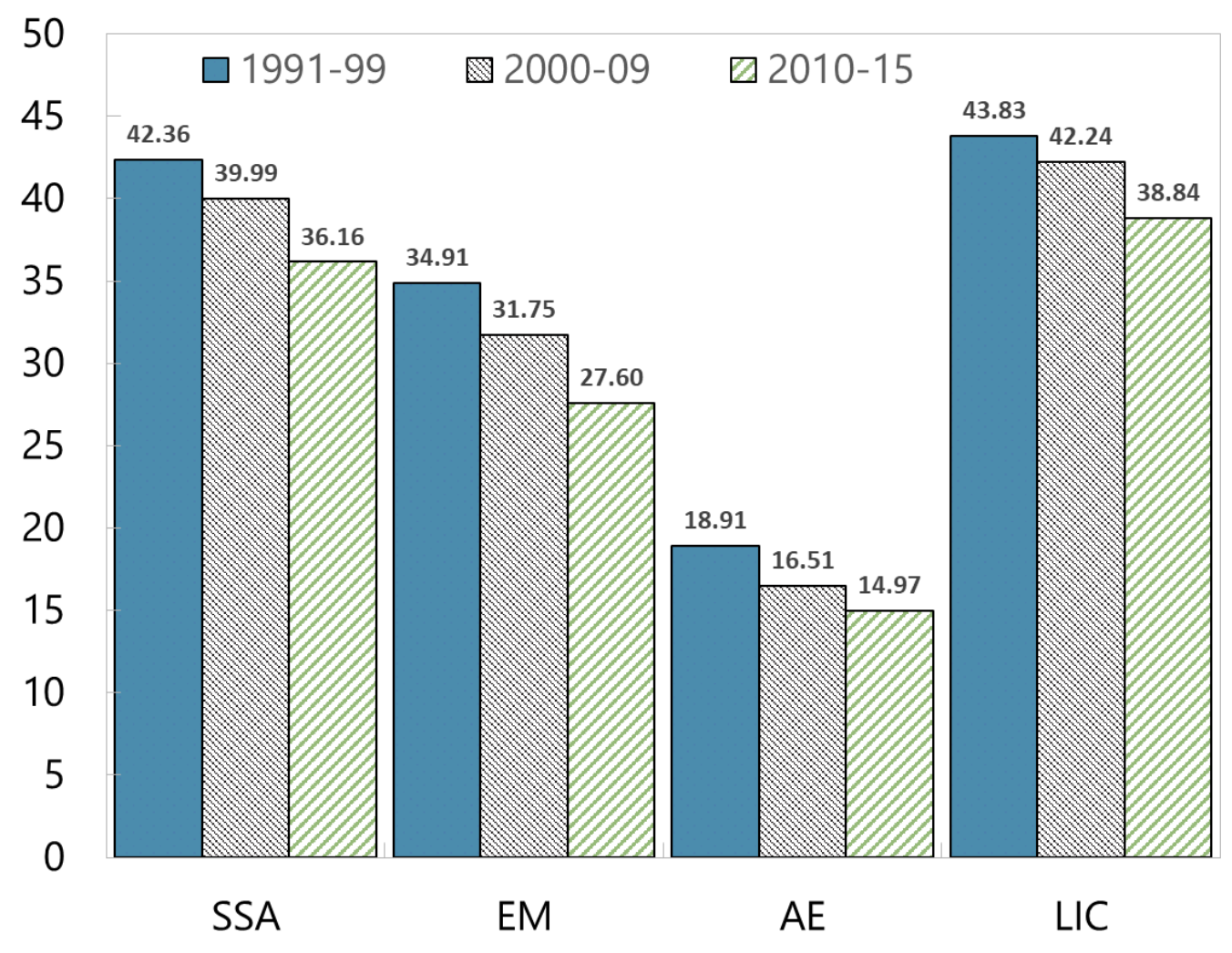

- Informality around the globe seems to fall with income, but particularly high in low-income countries. 


\section{Three robustness tests}

\section{Night lights instead of GDP}

\begin{tabular}{|c|c|c|c|c|c|c|}
\hline & (1) & (2) & (3) & (4) & (5) & (6) \\
\hline \multicolumn{7}{|l|}{ Causes } \\
\hline Trade openess & $-0.172^{\star \star \star}$ & $-0.167^{\star \star *}$ & $-0.106^{\star \star *}$ & $-0.178^{\star \star \star}$ & $-0.175^{\star \star \star}$ & $-0.161^{\star * *}$ \\
\hline Unemployment rate & $0.062^{\star *}$ & $0.061^{* *}$ & 0.008 & $0.067^{* *}$ & $0.068^{* * *}$ & $0.056^{\star *}$ \\
\hline Size of government & $0.106^{\star \star \star}$ & $0.101^{\star \star \star}$ & $0.036^{*}$ & & & \\
\hline Fiscal freedom & & & & $-0.150^{* * *}$ & $-0.153^{\star \star \star}$ & $-0.162^{\star \star *}$ \\
\hline Rule of law & $-0.065^{\star \star \star}$ & & & $-0.068^{* *}$ & & \\
\hline Control of corruption & & -0.042 & & & -0.035 & \\
\hline Government stability & & & $-0.183^{\star * *}$ & & & $-0.132^{\star \star \star}$ \\
\hline \multicolumn{7}{|l|}{ Indicators } \\
\hline Currency & 1 & 1 & 1 & 1 & 1 & 1 \\
\hline Labor force participation rate & $-0.457^{\star \star \star}$ & $-0.503^{* * *}$ & $-0.478^{\star * *}$ & $-0.226^{*}$ & $-0.244^{*}$ & $-0.230^{* *}$ \\
\hline Growth of GDP per capita & $-0.346^{\star *}$ & $-0.372^{\star \star \star}$ & $-1.838^{\star \star *}$ & $-0.275^{\star * *}$ & $-0.289^{\star \star *}$ & $-0.661^{* * *}$ \\
\hline \multicolumn{7}{|l|}{ Statistical Test } \\
\hline RMSEA & 0.023 & 0.027 & 0.079 & 0.052 & 0.053 & 0.082 \\
\hline$x^{2}$ & 125.015 & 116.891 & 548.593 & 158.781 & 151.93 & 307.091 \\
\hline Observations & 1341 & 1336 & 1767 & 1211 & 1210 & 1498 \\
\hline Countries & 148 & 148 & 120 & 139 & 139 & 116 \\
\hline
\end{tabular}




\section{Three robustness tests}

2. Compare results with National Accounts

(Rank correlation of 85 percent)

\begin{tabular}{lcc}
\hline Country & National Authorities & MIMIC \\
\hline Benin & 55.6 & 49.0 \\
Mali & 55.0 & 40.4 \\
Guinea-Bissau & 53.4 & 38.0 \\
Guinea & 48.1 & 37.0 \\
Senegal & 47.5 & 40.0 \\
Burkina Faso & 43.1 & 32.0 \\
Togo & 40.1 & 28.0 \\
Cote d'Ivore & 34.0 & 35.0 \\
\hline
\end{tabular}




\section{Three robustness tests}

\section{Predictive Mean Matching (PMM)}

- PMM (Rubin, 1987) treats the empirical challenge in estimating informal economy size as a missing data problem. We have estimates from some national authorities but not all.

- Using Bayesian techniques to produce estimates of informal economic activity, then grouping countries by similar informal economy size, and repeating, we produced lists of countries by low (less than 20\%), middle (20 to 40\%), and high (greater than 40\%) informal economies. 


\section{Main findings}

- Size of the informal economy is large in some regions (LAC and SSA) especially in SSA oil exporters and fragile states.

- Heterogeneity within regions.

- Informal sector acts as a safety net.

- Informal sector has low productivity and keeps productivity low in a vicious cycle.

- Governance, Doing Business, and Competitiveness Indicators are generally associated with the size of the informal sector. 


\section{Policy implications}

- Require a balanced approach for transition from the informal to the formal sector.

- Key policy recommendations to formalize the informal sector:

- Improve Governance, a necessary condition.

- Enhance Doing Business and Competitiveness Indicators, focusing on the indicators where the gap is largest compared to countries with smaller informal sectors.

- In particular, efficiency of financial markets 


\section{Thanks!}

Shadow Economies Around the World: What Did We Learn Over the Last 20 Years? Leandro Medina - International Monetary Fund The Economics of Informality May 28-29, 2018 Bogota, Colombia 